\title{
Temporary Electrician Helper Steps into Unguarded Elevator Shaft and Dies
}

\author{
Incident Number: 14KY039
}

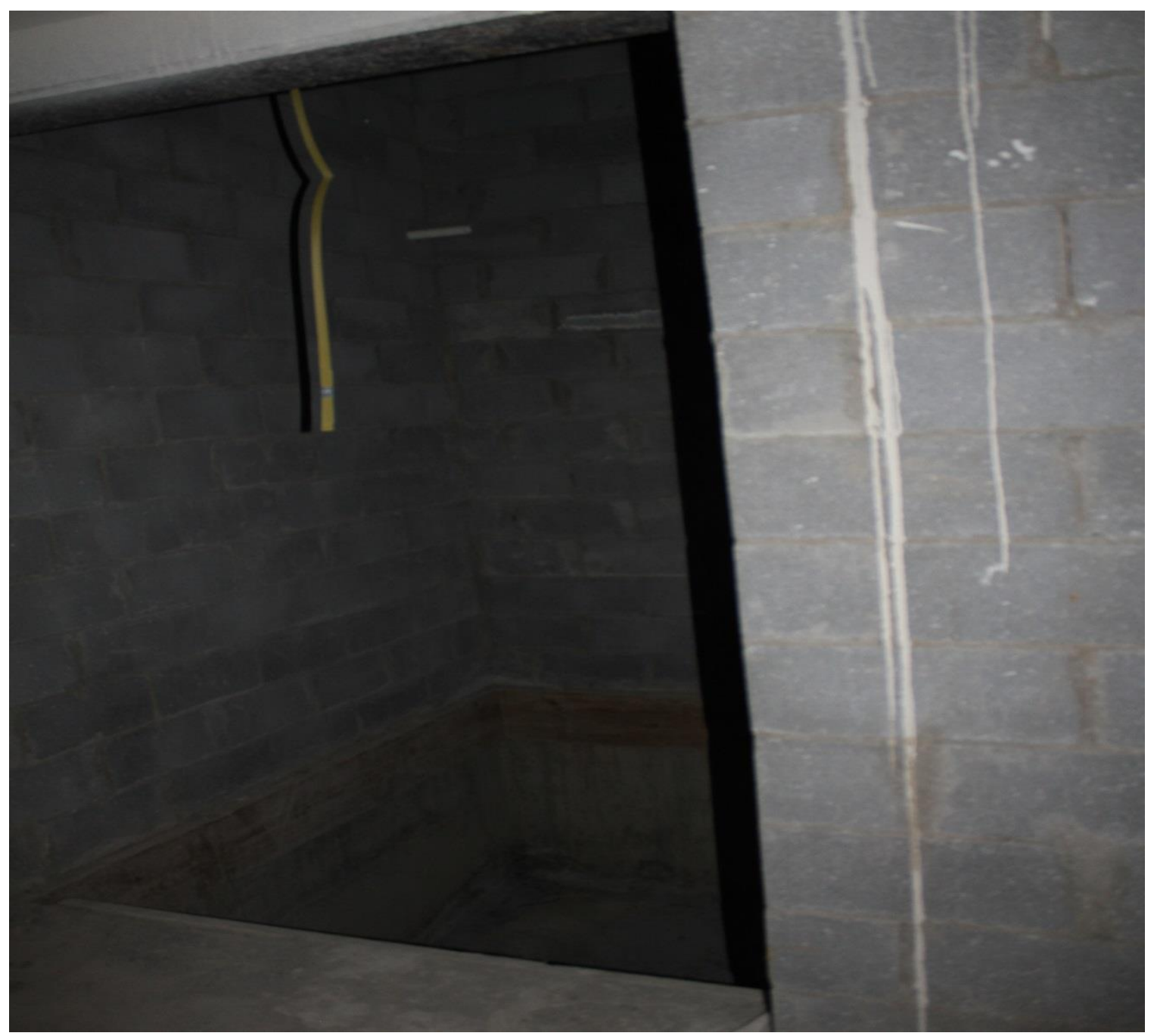

Photo courtesy of KY OSH

Kentucky Fatality Assessment and Control Evaluation Program Kentucky Injury Prevention and Research Center 333 Waller Avenue

Suite 242

Lexington, Kentucky 40504

Phone: 859-323-2981

Fax: 859-257-3909

www.kiprc.uky.edu

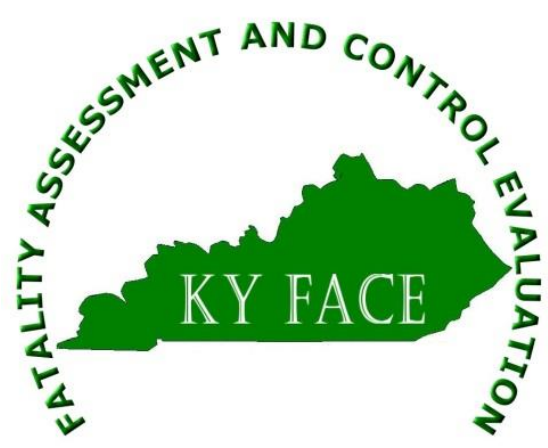




\section{Kentucky Fatality Assessment and Control Evaluation (FACE) Program Incident Number: 14KY039 \\ Release Date: September 28, 2015 \\ Subject: Electrician Helper Steps into Unguarded Elevator Shaft and Dies}

\section{Introduction}

July 16, 2014, a 34-year-old temporary electrician helper was laying out light fixtures to be installed in a commercial construction project when he stepped into an unguarded elevator shaft and fell 13 feet and 8 inches to his death. At approximately 5:00 pm, two sub-contracted painters were looking for empty buckets and found the victim at the bottom of the elevator shaft. It was unclear how long he had been there. Emergency Medical Services were notified and arrived on the scene, pronouncing the victim dead at 7:20 pm. His death was due to injuries sustained in the fall.

To prevent future occurrences of similar incidents, the following recommendations have been made:

Recommendation No. 1: Employers should guard all open areas where falls could occur. ${ }^{1}$

Recommendation No. 3: Employers should ensure that all working areas are well lit.

Recommendation No. 2: Employees should complete a minimum of 10 hours of safety training when hired. ${ }^{2}$

Recommendation No. 4: Employers should develop and implement drug free workplace policies and procedures to ensure a drug free workplace. ${ }^{3}$

Recommendation No. 5: Employers should hire experienced and qualified workers.

Recommendation No. 6: Temporary workers should be MADE AWARE of their rights as a worker, especially in regards to receiving safety training before beginning a job. ${ }^{4}$

\section{$\underline{\text { Employer }}$}

The electrical contractor, needing an electrician helper, placed an ad on Craigslist. The victim answered the ad and when he reported to work, was asked to complete paperwork from the temporary staffing agency. The electrical contractor provided electrical and communication services, including design, installation, testing, long-term service and maintenance to its clientele. The electrical contractor had 17 employees on this job site.

The temporary staffing agency was established in 2002 and is located in another state. The agency provides temporary employees to meet the needs of contractors working in the Atlantic 
and Southeast regions. The employer was a subcontractor on this site. At the time of the incident, the employer had offices in 6 states, employing approximately 1,000 employees.

\section{Written Safety Programs and Training}

The site supervisor stated he conducted basic safety training with the victim. He produced a copy of the sign-off sheet, where the victim had initialed and signed that he had received basic training. The basic training included injury and safety concern reporting, confined space entry, emergency action and evacuation, hazard communication, trenching and excavation, scaffold safety, ladder safety, lifting, tool safety, personal protective equipment and fall equipment, and GFCI protection. The temporary agency was not aware the victim had been hired by the electrical contractor at the time of the incident because paperwork had not been received by their out-of-state office.

\section{$\underline{\text { Victim }}$}

The victim, a 34-year-old married father of six children, was a high school graduate who had been employed with the company for one day prior to the fatality. His occupation was electrician helper. According to the victim's application he had no prior experience working in a construction setting.

\section{Incident Scene}

The scene was a commercial construction (four-story building) site. The elevator had yet to be installed, and the shaft opening was left open with no safety guards in place. The victim was laying out light fixtures to be installed in the second floor hallway by the elevator shaft. There was no lighting in or around the elevator shaft locations on the first and second floors. Footprints were observed on a small dusty pallet located in the passageway outside the $2^{\text {nd }}$ floor elevator shaft, indicating that employees had to walk over the pallet to navigate through this crowded area.

\section{$\underline{\text { Weather }}$}

July 16, 2014 was a mostly cloudy day with temperatures ranging from 68 to 78 degrees Fahrenheit. Weather was not considered a factor in this fatality.

\section{Investigation}

On July 16, 2014, the Kentucky Fatality Assessment and Control Evaluation Program was notified by the Kentucky Labor Cabinet of an occupational fatality involving an electrician helper.

The victim answered an ad that was posted on craigslist and received a call from the employer to come and fill out paperwork to begin working. After completing the paperwork on day one, the site supervisor sent the victim home to change his clothes from shorts to long pants. When he returned, he was still wearing tennis shoes instead of steeled toed boots, but the site supervisor 
allowed him to work. According to the victim's application, he had never worked in construction prior to this job and, therefore, was unaware of required proper attire on a construction worksite.

On day two, the victim was placing/laying out light fixtures for the electricians for each of the building's four floors for the entire day. The site supervisor last saw the victim between 1:00 pm and 1:30 pm on the second floor. At approximately 5:00 pm, painting contractor employees were on the first floor looking for buckets to wash their brushes when they saw the victim's tennis shoes in the bottom of the elevator shaft. They looked further down the elevator shaft and saw an unresponsive man. Though it was too dark to see well, they were not initially alarmed because there had been reports of people sleeping all over the building while on break. The painting employees immediately contacted their supervisor and returned with him to the scene. The supervisor climbed inside the elevator shaft and checked for vital signs and discovered the victim was cold, with no vitals and was deceased. It is unclear how much time had passed between the victim falling and subsequently being discovered.

The victim's cart, work belt, hardhat, safety glasses and light fixtures were found on the second floor hallway outside the $2^{\text {nd }}$ floor elevator shaft. There were two pallets directly placed outside the opening of the $2^{\text {nd }}$ floor elevator shaft with the plastic encasing the pallets. It was concluded that the victim fell 13 feet and 8 inches from the $2^{\text {nd }}$ floor elevator shaft opening to the bottom of the elevator shaft.

A 911 call was placed at 5:15 pm and homicide detectives arrived and secured the scene. Once it was determined not to be a homicide, the coroner was called to remove the body for autopsy. An autopsy revealed the victim sustained injuries that were conducive with a fall from height; the victim tested positive for Benzoylecgonine, Morphine, 6- monoacetylmorphoine, morphine, codeine and hydromorphone.

\section{Cause of Death}

The cause of death was multiple blunt force injuries of head, torso, and extremities sustained in a fall from height.

\section{$\underline{\text { Recommendations and Discussions }}$}

\section{Recommendation No. 1: Employers should guard all open areas where falls could occur. ${ }^{1}$}

In this incident, the elevator shaft was not guarded. In compliance with OSHA 1910 standard for walking and working surfaces, employers must place guards around all openings where falls could occur. All exposed sides must be guarded following the standards.

\section{Recommendation No.2: Employers should ensure that all working areas are well lit.}

The incident occurred in an area that was not well lit and the victim may not have been aware there was an elevator shaft nearby. According to OSHA 1915.82(c)(1), in a dark area that does not have permanent or temporary lights, or where lights are not working or are not readily 
accessible, the employer shall provide portable or emergency lights and ensure that employees do not enter those areas without adequate lighting.

Recommendation No. 3: Employees should complete a minimum of 10 hours of safety training when hired. ${ }^{2}$

Due to the various subjects and standards required by OSHA, it is important to cover all required construction safety training. A minimum of 10 hours of training should be completed that covers OSHA standards for the Construction Industry. Employees receive a 10 hour certification card for completing the course.

Recommendation No. 4: Employers should develop and implement drug free workplace policies and procedures to ensure a drug free workplace. ${ }^{3}$

Employers who develop and implement drug free workplace policies and procedures reduce their risk of employees reporting to work under the influence of drugs or alcohol. Employers who drug test before hiring can determine which employees would be a significant liability to their companies. Had the employer in this case preformed a pre-hire drug test, he would have realized the victim was under the influence of illegal drugs and could have rejected the offer of employment.

\section{Recommendation No. 5: Employers should hire experienced and qualified workers.}

The victim's application revealed he had not had any prior experience in construction type work. His past experience had been with a retail store assembling grills and patio furniture. By hiring experienced and qualified workers, the employer reduces his liability of risk of unsafe work due to lack of knowledge.

Recommendation No. 6: Temporary workers should be MADE AWARE of their rights as a worker, especially in regards to receiving safety training before beginning a job.

Both staffing agencies as well as their client employers share a legal obligation to provide workplaces free of recognized hazards, including providing safety training to employees. ${ }^{4}$

\section{$\underline{\text { Keywords }}$}

Construction falls

Open walkways

Guarding openings

Worker Fatality

Worker safety

OSHA

Occupational safety 


\section{$\underline{\text { References }}$}

${ }^{1} 29$ C.F.R. 1910.23- Guarding floor and wall openings and holes. OSHA.

[https://www.osha.gov/pls/oshaweb/owadisp.show_document?p_table=STANDARDS\&p_id=97 15]. Accessed February 10, 2015.

${ }^{2}$ OSHA Outreach Training Program. OSHA. [https://www.osha.gov/dte/outreach/]. Accessed on February 10, 2015.

${ }^{3}$ Drug-Free Workplace Advisor. United States Department of Labor.

[http://www.dol.gov/elaws/drugfree.htm]. Accessed on February 10, 2015.

${ }^{4}$ Temporary workers face unnecessary, life-threatening hazards. OSHA.

[https://www.osha.gov/temp_workers/OP_ED_Bay_Area.html] Accessed on March 6, 2015.

\section{$\underline{\text { Acknowledgements }}$}

The Kentucky FACE program would like to thank the Police Department, Kentucky OSHA, and the Coroner's office for their assistance with this report.

The Kentucky Fatality Assessment \& Control Evaluation Program (FACE) is funded by grant 2U60OH008483-11 from the Centers for Disease Control and Prevention and the National Institute for Occupational Safety and Health. The purpose of FACE is to aid in the research and prevention of occupational fatalities by evaluating events leading to, during, and after a work related fatality. Recommendations are made to help employers and employees have a safer work environment. For more information about FACE and KIPRC, please visit our website: www.kiprc.uky.edu 


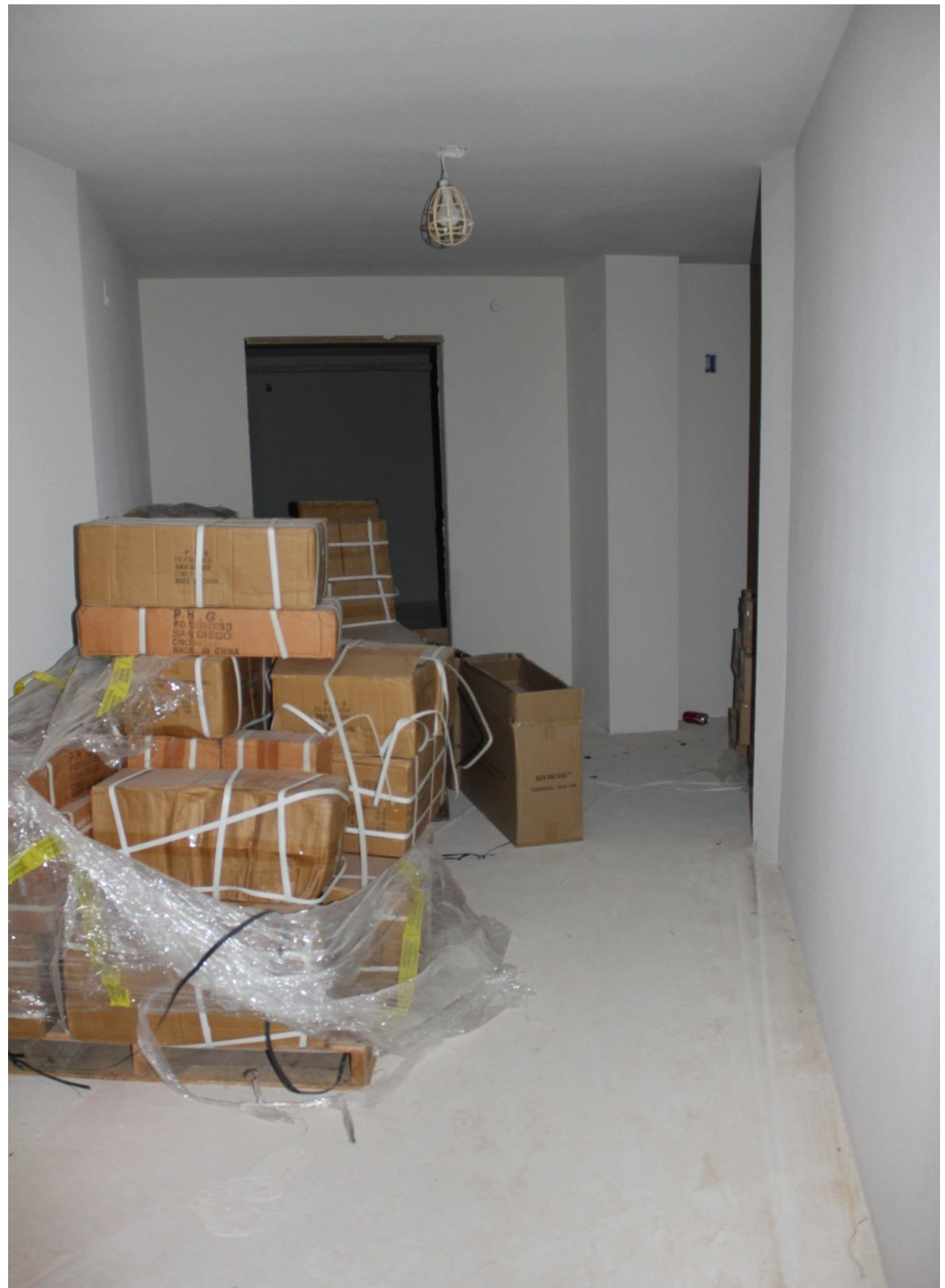

Pallets and boxes cluttering the hallway work area.

Photo courtesy of KY OSH 


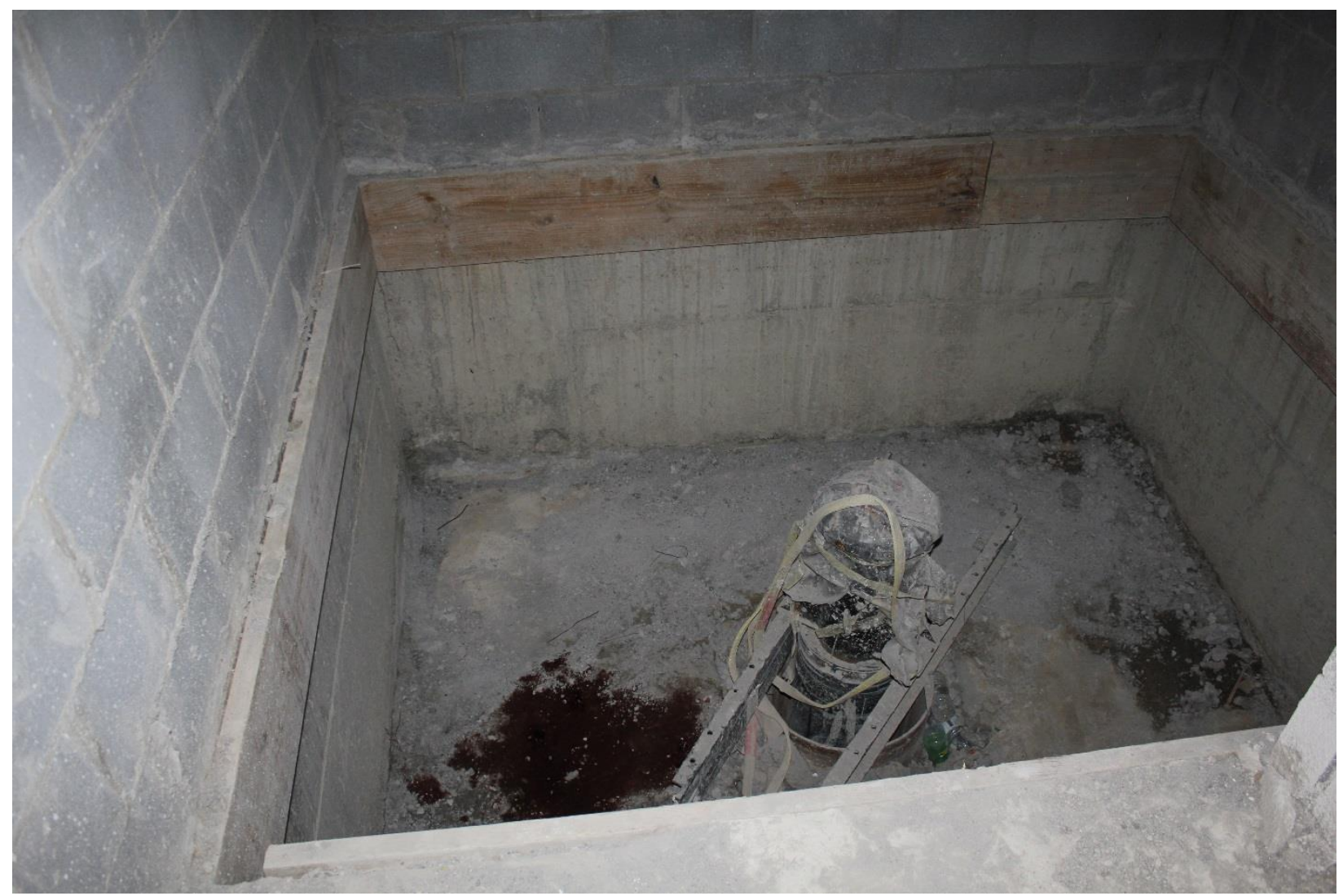

First floor landing inside elevator shaft where the victim landed. Photo courtesy of KY OSH 